\title{
IMPLEMENTASI PELAYANAN KREDIT USAHA RAKYAT PT. BANK RAKYAT INDONESIA UNIT NATAR DI KABUPATEN LAMPUNG SELATAN
}

\author{
Ayu Nadia Pramazuly, S.I.P.,M.I.P', Rosidah, S.Sos., M.Si. ${ }^{2}$ \\ ayunadiapramazuly@gmail.com ${ }^{1}$ idahros40@gmail.com² \\ ${ }^{[1][2]}$ Program Studi Administrasi Publik, Fakultas Ilmu Sosial dan Ilmu Politik, UTB Lampung
}

\begin{abstract}
ABSTRAK
Penelitian ini dilatarbelakangi oleh adanya wacana mengenai pemberian kredit untuk usaha kecil, menengah, dan koperasi, sebagai upaya pemerintah memberikan subsidi kepada pelaku usaha. Program Kredit Usaha Rakyat (KUR) yang merupakan program mikro pemerintah yang diharapkan mampu meningkatkan kesejahteraan Usaha Mikro Kecil, dan Menengah (UMKM) dan Koperasi. Pemerintah juga mendorong peningkatan akses Usaha Mikro Kecil, dan Menengah (UMKM) dan Koperasi kepada kredit atau pembiayaan dari perbankan melalui peningkatan kapasitas Perusahaan Penjamin, sehingga Usaha Mikro Kecil, dan Menengah (UMKM) dan Koperasi yang selama ini mengalami kendala atau kesulitan dalam mengakses kredit atau pembiayaan dari perbankan dapat diatasi. Pelaksanaan Kredit Usaha Rakyat (KUR) dipilih karena seringkali terjadi kesalahpahaman persepsi mengenai agunan, yang mengakibatkan terjadinya pengembalian kredit yang tidak tepat waktu atau kredit bermasalah. Penelitian ini menggunakan metode penelitian deskriptif kualitatif yang berlokasi penelitian di Kantor BRI Unit Natar Kabupaten Lampung Selatan.
\end{abstract}

Kata Kunci: Pelayanan, Kredit Usaha Rakyat

\section{PENDAhUluan}

\begin{tabular}{lrr}
\multicolumn{1}{c}{ Pada hakekatnya } & tujuan \\
pembangunan & suatu & negara \\
dilaksanakan & adalah & untuk \\
mewujudkan kesejahteraan masyarakat, \\
demikian halnya & dengan $r$ & tujuan \\
dibentuknya negara Indonesia. & Untuk \\
mewujudkan tujuan tersebut \\
dilaksanakanlah
\end{tabular}

Berbagai rencana dan programprogram pembangunan sebagai wujud pelaksanaan pemerintahan telah dibuat dan diimplementasikan di daerahdaerah, baik yang dilaksanakan oleh pemerintah pusat pemerintah daerah itu sendiri. Salah satu program pemerintah yaitu pembangunan perekonomian masyarakat yang didorong adanya program pro masyarakat.

Partisipasi masyarakat merupakan modal utama dalam upaya mencapai sasaran program pemerintah di seluruh wilayah Republik Indonesia. Keberhasilan dalam pencapaian sasaran pelaksanaan program pembangunan perekonomian bukan semata-mata didasarkan pada kemampuan aparatur pemerintah, tetapi juga berkaitan dengan upaya mewujudkan kemampuan dan keamanan masyarakat untuk berpartisipasi dalam pelaksanaan program pembangunan perekonomian masyarakat. Adanya partisipasi masyarakat akan mampu mengimbangi 
keterbatasan. Berbagai upaya yang dilakukan oleh pemerintah untuk mensejahterakan masyarakatnya telah dilakukan, namun upaya tersebut selalu mendapatkan hasil yang kurang memuaskan. Pemerintahpun mengeluarkan kebijakan kembali yang kegunaannya yaitu untuk mengembangkan perekonomian masyarakat kecil yang memiliki usaha mikro, kecil menengah (UMKM).

Berdasarkan Undang-undang No. 20 Tahun 2008 tentang UMKM diperoleh pengertian bahwa: Usaha Mikro adalah usaha produktif milik orang perorangan dan/atau badan usaha perorangan yang memenuhi kriteria Usaha Mikro sebagaimana diatur dalam UndangUndang ini. Usaha Kecil adalah usaha ekonomi produktif yang berdiri sendiri, yang dilakukan oleh orang perorangan atau badan usaha yang bukan merupakan anak perusahaan atau bukan cabang perusahaan yang dimiliki, dikuasai, atau menjadi bagian baik langsung maupun tidak langsung dari usaha menengah atau usaha besar yang memenuhi kriteria Usaha Kecil sebagaimana dimaksud dalam UndangUndang ini. Usaha Menengah adalah usaha ekonomi produktif yang berdiri sendiri, yang dilakukan oleh orang perseorangan atau badan usaha yang bukan merupakan anak perusahaan atau cabang perusahaan yang dimiliki, dikuasai, atau menjadi bagian baik langsung maupun tidak langsung dengan Usaha Kecil atau usaha besar dengan jumlah kekayaan bersih atau hasil penjualan tahunan sebagaimana diatur dalam Undang-Undang ini.

Beberapa literatur (Firdausy, 2005; LIPI, 2014) mengungkapkan UMKM juga berperan penting dalam percepatan penanggulangan kemiskinan. UMKM menghasilkan barang dan jasa yang menjadi kebutuhan utama masyarakat kelas ekonomi menengah ke bawah. Sekitar 67 persen dari tenaga kerja yang terlibat di UMKM merupakan kelas menengah ke bawah (LIPI, 2014). Dengan demikian, UMKM tidak hanya menjadi sumber penciptaan kesempatan kerja dan pendapatan bagi masyarakat menengah-bawah, tetapi juga menjadi sumber bagi mereka untuk memenuhi kebutuhan hidupnya.

Dalam rangka pemberdayaan usaha mikro, kecil dan menengah (UMKM), penciptaan lapangan kerja, dan penanggulangan kemiskinan, pemerintah mengeluarkan Inpres No. 06 Tahun 2007 tentang Kebijakan Percepatan Pengembangan Sektor Riil dan Pemberdayaan UMKM. Salah satu langkah penting dari implementasi Inpres ini adalah peluncuran Kredit Usaha Rakyat (KUR). Adapun Bank Pelaksana yang menyalurkan KUR ini adalah Bank BRI, Bank Mandiri, Bank BNI, Bank TN, Bank Syariah Mandiri, dan Bank Bukopin (Komite Kredit Usaha Rakyat).

Dalam mendorong pertumbuhan sektor mikro yang identik dengan Usaha Mikro, Kecil dan Menengah (UMKM), pemerintah memberikan subsidi bunga kredit kepada bank 
pelaksana kredit mikro agar suku bunga kredit turun. Tata cara subsidi bunga ini tertuang dalam Peraturan Kementrian Keuangan No. 146/PMK.05/2015 tentang Tata Cara Pelaksanaan Subsidi Bunga untuk Kredit Usaha Rakyat. Untuk Bank Pelaksana, Pemerintah akan membayarkan sebesar $7 \%$ per tahun untuk kredit mikro, $3 \%$ per tahun untuk kredit ritel, dan $12 \%$ per tahun untuk kredit tenaga kerja Indonesia. Penetapan besaran subsidi bunga dilakukan oleh Menteri Keuangan dengan mempertimbangkan kemampuan pemerintah menyediakan alokasi belanja subsidi.

Kredit usaha rakyat adalah kredit atau pembiayaan yang diberikan kepada UMKM yang feasible tapi belum bankable. Maksud dari feasible dan bankable adalah usaha tersebut memiliki prospek bisnis yang baik dan memiliki kemampuan untuk mengembalikan meski belum masuk dalam kategori memenuhi persyaratan bank.

UMKM diharapkan dapat mengakses Kredit Usaha Rakyat (KUR) adalah yang bergerak di sektor usaha produktif antara lain: pertanian, perikanan, kelautan, dan perindustrian, kehutanan dan jasa keuangan simpan pinjam. Penyaluran KUR dapat dilakukan secara langsung. Maksudnya UMKM dapat langsung mengakses KUR di kantor cabang atau kantor cabang pembantu Bank pelaksana. Dapat juga di lakukan secara tidak langsung, maksudnya usaha mikro dapat mengakses KUR melalui lembaga keuangan yang bekerjasama dengan Bank Pelaksana KUR.

Secara teknis, mekanisme penyaluran KUR seperti telah disepakati dalam Standar Operasional Prosedur (SOP) program KUR adalah bahwa para pelaku UMKM yang sudah feasible tetapi belum bankable mengajukan aplikasi pinjaman ke bankbank penyalur KUR. Bank penyalur kemudian menganalisis aplikasi. Apabila disetujui, bank akan melaporkan data pinjaman tersebut ke perusahaan penjamin kredit yang ditunjuk.

\section{Gambar 1. Realisasi dan Penyaluran KUR Menurut Bank}

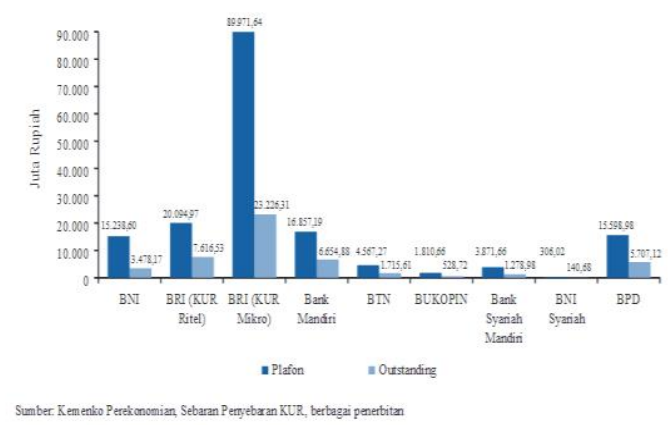

Dirinci menurut bank pelaksana, BRI menjadi bank dengan kemampuan menyalurkan KUR terbesar (leading bank) Sekitar 65,4\% (KUR Mikro 53,5 persen dan KUR Ritel 11,9\%) dari total KUR disalurkan melalui BRI. Kemampuan BRI menjadi leading bank dalam penyaluran KUR tidak terlepas dari dukungan keuangan (financial capacity), kuatnya pemahaman, dan panjangnya pengalaman sebagai penyalur kredit mikro (micro credit business capability), serta terbangunnya kualitas sumber daya 
manusia. Dalam kaitan dengan sumber daya manusia, misalnya berbeda dengan bank lainnya BRI mengangkat account officer khusus, disebut Mantri KUR. Mantri KUR adalah ujung tombak penyaluran, pemasaran dan pencarian nasabah potensial.

Struktur manajemen BRI juga lebih siap untuk menyalurkan KUR dengan memiliki BRI Unit yang khusus menyalurkan KUR Mikro, sementara KUR Ritel ditangani account officer di kantor cabang. Sistem reward and punishment dilaksanakan sebagai salah satu instrumen untuk menjaga kualitas account officer. Dengan sistem yang terbangun tersebut, tidak mengherankan jika BRI mampu meningkatkan ekspansi kredit (KUR) tanpa mendorong terjadinya peningkatan risiko kredit bermasalah.

Kecamatan Natar merupakan daerah administrasi yang berada di Kabupaten Lampung Selatan. Kecamatan Natar berada di jalur Lintas Sumatera dan merupakan akses jalan menuju Ibu Kota Provinsi Lampung. Perekonomian di Kecamatan Natar ditopang oleh usaha-usaha kecil yang dimiliki oleh masyarakatnya. Mayoritas penduduk bertahan hidup dengan berdagang, berternak, dan bertani.

Program KUR di Kecamatan Natar sangat diminati oleh masyarakat. Ditambah lagi karena di daerah ini mayoritas merupakan tempat sentra usaha-usaha mikro, kecil dan menengah. Berdasarkan penjabaran di atas, peneliti tertarik mengangkat judul Implementasi Pelayanan Kredit Usaha
Rakyat PT. Bank Rakyat Indonesia Unit Natar Kabupaten Lampung Selatan.

\section{METODE}

Penelitian ini menggunakan metode penelitian dengan pendekatan kualitatif deskriptif. Penelitian deskriptif yaitu penelitian yang dilakukan untuk mengetahui nilai variabel mandiri, baik satu variabel atau lebih (independent) tanpa membuat perbandingan, atau menghubungkan antara variabel satu dengan variabel yang lainnya. Alasan dari dipilihnya metode ini dikarenakan pemahaman terhadap permasalahan lebih bersifat kualitatif yang didasarkan pada persepsi, eksplolari pemikiran, dan pengembangan konsep.

\subsection{Fokus Penelitian}

Batasan masalah dalam penelitian kualitatif disebut sebagai fokus, yang berisi masalah yang masih bersifat umum. Penetapan fokus dalam penelitian kualitatif sangat penting untuk membatasi studi dan mengarahkan pelaksanaan suatu pengamatan. Fokus penelitian dalam penelitian ini berdasarkan latar belakang dan tujuan penelitian, yaitu:

1. Implementasi diukur dari kepatuhan penyedia pelayanan.

2. Implementasi diukur dari kelancaran rutinitas dan tidak adanya persoalan. 
3. Implementasi yang berhasil mengarah pada kinerja yang memuaskan semua pihak.

\subsection{Lokasi Penelitian}

Penelitian ini berlokasi di PT. Bank Rakyat Indonesia, Tbk. Unit Natar, sebagai pelaksana kebijakan pusat maupun daerah yang memberikan pelayanan langsung kepada nasabah yang hendak mengajukan Kredit Usaha Rakyat (KUR).

\subsection{Teknik Pengumpulan Data}

Teknik pengumpulan data yang digunakan dalam penelitian ini adalah:

1. Wawancara

Dalam penelitian ini teknik wawancara digunakan sebagai cara untuk mengumpulkan data. Percakapan ini dilakukan oleh dua pihak, yaitu pewawancara yang mengajukan pertanyaan dan yang diwawancara yang memberikan jawaban atas pertanyaan adalah karyawan PT. Bank Rakyat Indonesia dan Penerima pelayanan yaitu pemilik UMKM.

2. Dokumentasi

Penggunaan metode dokumentasi ini ditujukan untuk melengkapi dan memperkuat data dari hasil wawancara. Dokumentasi dapat berupa data maupun foto-foto yang diambil ketika penelitian berlangsung.

\subsection{Teknik Analisis Data}

Analisis data dalam bukunya Sugiyono (2008) adalah proses mengatur urutan data ke dalam suatu pola, kategori dan satuan uraian besar. Analisis data menggunakan analisis deskriptif yang sifatnya induktif, yaitu berusaha untuk memperoleh kesimpulan berdasarkan pemikiran yang alamiah dari berbagai jawaban yang diperoleh atau mencoba mendalami dan meneropong gejala sosial-politik dengan menginterpretasikan masalah yang terkandung di dalamnya.

\section{ANALISIS HASIL DAN PEMBAHASAN}

\subsection{Manajemen dan Struktur Organisasi PT. Bank Rakyat Indonesia}

Salah satu bank terbesar yang ada di Indonesia adalah Bank BRI. Kantor Pusat Bank BRI berkedudukan di Jl. Jendral Sudirman Kavling 44-46 Jakarta 10210, Indonesia. Sejalan dengan pertumbuhan usaha Bank BRI yang semakin pesat, data per September 2004 memperlihatkan Bank BRI mempunyai unit kerja yang terdiri dari 1 kantor pusat, 13 kantor wilayah, 325 kantor cabang (dalam negeri), 163 kantor cabang pembantu, 16 cabang bank syariah, 1 kantor cabang khusus, 1 kantor New York Agency, 1 kantor cabang Cayman Island, 1 kantor perwakilan Hongkong, 4.046 Bank BRI unit dan 140 pos pelayanan desa dengan jumlah pegawai mencapai 36.715 orang. Terkait dengan usahanya, Bank BRI membagi manajemen perusahaannya 
menjadi beberapa bagian, yaitu: (1) Bisnis mikro dan ritel, (2) Bisnis menengah, (3) Pengendalian kredit, (4) Keuangan dan international,

Operasional, dan (6) Kepatuhan.

\subsection{Kegiatan Usaha Bank Rakyat Indonesia}

Bank BRI menjalankan usahanya melalui divisi-divisi bisnis mikro, bisnis ritel, bisnis umum, unit bisnis syariah serta divisi treasury dan internasional. Fokus bisnis yang mengarah pada pemberdayaan usaha mikro telah menjadi basis yang kuat yang menempatkan Bank BRI sebagai bank terbesar ke dua dari sisi penyaluran kredit.

Bank BRI melayani nasabah mikro melalui jaringan unit yang diperpanjang dengan Pos Pelayanan Desa (PPD). Jaringan bisnis yang dibangun Bank BRI merupakan unsur pendukung utama sehingga Bank BRI dapat menguasai segmen ini. Produk yang dikelola oleh divisi ini adalah produk pinjaman dan produk simpanan. Produk pinjaman yang ditawarkan berupa Kupedes Modal Kerja dan Kupedes Investasi yang diberikan kepada pengusaha mikro dan pelaku usaha lainnya serta Kupedes untuk golongan berpenghasilan tetap yang diberikan untuk pekerja perusahaan swasta, lembaga-lembaga pemerintah, Badan Usaha Milik Negara (BUMN), terutama pegawai negeri sipil dan pensiunan. Produk simpanan berupa giro, tabungan dan deposito berjangka (termasuk sertifikat deposito).
Bisnis ritel dilaksanakan melalui kantor wilayah, kantor cabang, dan kantor cabang pembantu. Divisi ritel menyediakan kredit untuk perusahaan kecil dan menengah (UKM), termasuk perusahaan swasta dan perusahaan perorangan. Produk pinjaman yang diberikan adalah kredit modal kerja dan kredit investasi yang diberikan kepada UKM, serta kredit Golbertap yang diberikan kepada perorangan yang bekerja pada perusahaan swasta, BUMN, dan Institusi Pemerintah. Produk simpanan berupa tabungan, giro, deposito berjangka dan sertifikat deposito yang dikelola divisi consumer banking. Produk lain yang ditawarkan adalah Letter of Credit (L/C), bank garansi, produk-produk treasury dan reksa dana melalui relationship manager.

Bisnis menengah meliputi komersial, kredit korporasi dan agribisnis. Kredit komersial diberikan kepada nasabah dalam jumlah lima miliar rupiah sampai dengan 50 miliar rupiah. Kredit korporasi merupakan fasilitas kredit diatas 50 miliar rupiah, sedangkan kredit agribisnis diberikan kepada debitur yang bergerak dalam industri agribisnis.

Bidang usaha consumer banking menawarkan kredit kendaraan bermotor, kredit kepemilikan rumah dan kredit talangan haji. Produk simpanan berupa tabungan, giro, deposito berjangka dan sertifikat deposito. Produk lain yang ditawarkan adalah kartu debit, kartu kredit, jasa pembayaran tagihan, jasa pengiriman dana dan safe deposit box. 
Produk pendanaan yang ditawarkan Bank BRI antara lain berupa tabungan, giro, deposito berjangka dan sertifikat deposito yang diberikan kepada nasabah mikro, ritel, UKM, BUMN dan pemerintah.

Produk pendanaan berupa Simpedes, Simaskot, Britama Rupiah, Britama Dollar, Giro dan Deposito Berjangka. Simpedes merupakan tabungan yang ditawarkan melalui Bank BRI unit, ditawarkan kepada nasabah yang menginginkan tabungan yang aman dan nyaman. Simaskot ditawarkan melalui Bank BRI unit yang terletak di kota. Britama Rupiah ditawarkan melalui kantor cabang dan kantor cabang pembantu. Britama Dollar merupakan produk tabungan dalam mata uang asing yaitu Dollar AS.

\section{REFERENSI}

Djumhana, Muhammad. 2000. Hukum Perbankan di Indonesia. PT Citra Aditya Bakti. Bandung.

Dwiyanto, Agus. 2014. Mewujudkan Good Governance Melalui Pelayanan Publik. Gadja Mada University Press. Yogyakarta.

Frederickson, $\quad$ George. 1987 Administrasi Negara Baru. LP3ES. Jakarta.

Fuady, Munir. 1996. Hukum Bisnis Dalam Teori dan Praktek. Buku I. PT. Citra Aditya Bakti. Bandung.

Ibrahim, Amin. 2008. Teori dan Konsep Pelayanan Publik Serta
Implementasinya. Mandar Maju. Bnadung.

Moenir. 2006. Manajemen Pelayanan Umum di Indonesia. Bumi Aksara. Jakarta

Noor, Juliansyah, 2011. Metodologi Penelitian: Skripsi, Tesis, Disertasi, dan

Karya Ilmiah. Cetakan 1. Kencana Prenada Media Group. Jakarta.

Prasojo, Eko. 2006. Kinerja Pelayanan Publik. Yappika. Jakarta.

Rahman, Hasanuddin II.1998.AspekAspek Hukum Pemberian Kredit Perbankan di Indonesia (PanduanDasar Legal Officer). PT. Citra Aditya Bakti. Bandung.

Sjahdeini, St.Remy. 1993. Beberapa Masalah Hukum di Sekitar Perjanjian Kredit Bank. Simposium Perbankan. Medan.

Suyatno, Thomas, dkk.1998. Dasardasar Perkreditan. Gramedia Pustaka Utama. Jakarta.

\section{Peraturan Perundang-undangan:}

Inpres No. 6 Tahun 2007 tentang Kebijakan Percepatan Sektor Riil dan Pemberdayaan UKM.

Keputusan MENPAN Nomor 63 Tahun 2003 tentang Pedoman Umum Penyelenggaraan Pelayanan Publik.

\section{Website :}

www.bri.co.id diakses pada 20 Oktober 2016 